\title{
SERUM Ca, K, AND Na LEVELS IN DAIRY COWS WITH RETAINED PLACENTA AND DYSTOCIA
}

\author{
Hallouz Hadj Feghoul $^{1}$, Meliani Samia ${ }^{2 *}$, Benallou Bouabdellah ${ }^{1}$ \\ ${ }^{1}$ Institute of Veterinary Sciences, University of Tiaret, Algeria; \\ ${ }^{2 *}$ Faculty of Natural Sciences and Life, University of Tiaret, Algeria;
}

*Corresponding Author Meliani Samia, e-mail: meianisamia@ @otmail.com;

Received November 2020; Accepted December 2020; Published March 2021;

DOI: https://doi.org/10.31407/ijees11.203

\begin{abstract}
The aim of this study was to determine the evolution serum levels of $\mathrm{Ca}, \mathrm{K}$, and $\mathrm{Na}$ in dairy cows with retained placenta (RP) and dystocia. Fourty-five cows between 3-10 years old were used in the study. Jugular blood samples were collected via hiparined vacutainer tubes. The samples were centrifuged and the serum samples were stored at $20^{\circ} \mathrm{C}$ until analyse. Calcium $(\mathrm{Ca})$, Sodium $(\mathrm{Na})$, and Potassium $(\mathrm{K})$ were determined in all samples using a Roch ${ }^{\circledR}$ COBAS Integra 400. In this study, Na serum levels were significantly higher $(\mathrm{p}<0,05)$ in 48 post-partum hours' cows with $139,91 \pm 7,1 \mathrm{mmol} / \mathrm{l}$ compared with dry period with $131,09 \pm 11,09 \mathrm{mmol} / \mathrm{l}$. However, mean serum calcium levels were $79,50 \pm 10,47$ and $79,25 \pm 8,39 \mathrm{mg} / \mathrm{l}$ in cows with retained placenta in dry period and 48 hours' postpartum, respectively. The mean serum sodium levels in cows with retained placenta in dry period and 48 hours postpartum were $134,00 \pm 10,99$ and $137,88 \pm 5.64 \mathrm{mmol} / 1$ respectively. Whereas, in case of cows without retained placenta, the sodium values for the same period were130,46 $\pm 11,15$ and $140,35 \pm 7,37 \mathrm{mmol} / 1$, respectively. In this study, the serum $\mathrm{Ca}, \mathrm{Na}$ and $\mathrm{K}$ concentrations of the cows with RP did not change significantly from other cows without. Furthermore, it was detected that these variables had no significant effect on serum $\mathrm{Ca}, \mathrm{K}$ and $\mathrm{Na}$ concentrations when type of parturition and sex of calves were evaluated in the RP and control group.
\end{abstract}

Keywords: serum $\mathrm{Ca}, \mathrm{K}, \mathrm{Na}$ levels, dairy cows, retained placenta, dystocia, control group 